\title{
Prevalence of Neospora caninum antibodies in sheep flocks of Uberlândia county, MG
}

\author{
Prevalência de anticorpos anti-Neospora caninum em rebanhos de ovinos do município de Uberlândia, MG
}

Sandra Renata Sampaio Salaberry ${ }^{1 *}$; Liria Hiromi Okuda ${ }^{2}$; Alessandra Figueiredo de Castro Nassar ${ }^{2}$; Jacqueline Ribeiro de Castro $^{1}$; Anna Monteiro Correia Lima-Ribeiro ${ }^{1}$

${ }^{1}$ Faculdade de Medicina Veterinária - FAMEV, Universidade Federal de Uberlândia - UFU

${ }^{2}$ Centro de Pesquisa e Desenvolvimento de Sanidade Animal, Instituto Biológico

Received February 3, 2010

Accepted April 19, 2010

\begin{abstract}
Neosporosis is a parasitic disease that occurs in sheep and is associated with reproductive failure. The aim of this study was to verify seroprevalence of Neospora caninum antibodies in 12 sheep flocks in Uberlândia county, Minas Gerais, Brazil, using Indirect Immunofluorescence Assay (IFA). A total of 334 sheep blood samples were analyzed and an epidemiologic questionnaire was applied for each farm in order to correlate with risk factors of neosporosis: gender, age, breed, abortion problems, contact with cattle and dogs, and presence of wild canids. The prevalence of Neospora caninum antibodies in sheep was $8.1 \%$, with titers ranging from 50 to 3200 and $83.3 \%$ of farms detected at least one ovine reactive. There was statistically significant difference in flocks with abortion problems associated with the presence of Neospora caninum antibodies ( $\mathrm{p}<0.05)$.
\end{abstract}

Keywords: Neosporosis, sheep, immunofluorescence assay, seroprevalence.

\section{Resumo}

A neosporose é uma doença parasitária que acomete os ovinos e está associada a perdas reprodutivas. O objetivo deste estudo foi verificar a prevalência de anticorpos anti-Neospora caninum em 12 rebanhos de ovinos do município de Uberlândia, MG, utilizando a Técnica de Imunofluorescência Indireta (RIFI). Foram analisadas 334 amostras de sangue e, em cada propriedade, aplicou-se um questionário epidemiológico para avaliar os fatores de risco envolvidos na transmissão desse protozoário: sexo, idade, raça, problemas de aborto, contato com bovinos e caninos e presença de canídeos silvestres. A prevalência de anticorpos anti-Neospora caninum em ovinos foi de 8,1\%, com títulos variando de 50 a 3200 e $83,3 \%$ das propriedades apresentaram pelo menos um ovino reagente. Houve diferença estatística significativa para rebanhos com problemas de aborto associados à presença de anticorpos anti-Neospora caninum $(\mathrm{p}<0,05)$.

Palavras-chave: Neosporose, ovina, reação de imunofluorescência, soroprevalência.

\section{Introduction}

Neosporosis is an infection caused by the coccidian parasite Neospora caninum (N. caninum). Until now dogs and coyotes have been identified as the definitive hosts, although infection with $N$. caninum has been occasionally reported in other animal species such as ovines, caprines, cervids, and equines (DUBEY, 2003; GONDIM et al., 2004).

Infected dogs release oocysts of $N$. caninum in the soil with the feces, contaminating the environment and infecting susceptible species (HELMICK et al., 2002). Herbivorous animals are infected

*Corresponding author: Sandra Renata Sampaio Salaberry Faculdade de Medicina Veterinária - FAMEV,

Universidade Federal de Uberlândia - UFU, Av. Ceará, s/nº, Bloco 2D, sala 33, Campus Umuarama, CEP 38400-902, Uberlândia - MG, Brazil;

e-mail: sandrasalaberry@yahoo.com.br by ingestion of food and water contaminated by oocysts while dogs become infected by ingestion of tissues containing bradyzoites. Another form of infection is by vertical transmission across the placenta, when the tachyzoites of $N$. caninum are transferred to the fetus (DUBEY et al., 2007).

Infection with $N$. caninum in sheep does not have the same relevance as in cattle. However, in farms where there is joint raising of cattle and sheep, they may eventually participate in the epidemiology of infection (VOGEL et al., 2006). Occasionally the infection can cause miscarriages and sick newborns (BÁRTOVÁ et al., 2009).

The presence of the parasite in sheep flocks can be verified by the detection of serum antibodies or by isolation and molecular identification of the parasite. Many countries, including 
Slovakia, have reported antibodies against $N$. caninum in their sheep flocks (SPILOVSKÁ et al., 2009). In Brazil, serological surveys have demonstrated prevalence of infection ranging from 6.4 to 29\% (AGUIAR et al., 2004; FIGLIUOLO et al., 2004; ROMANELLI et al., 2007; UENO et al., 2009). Pena et al. (2007) reported the first isolation and molecular characterization of $N$. caninum in the brain of naturally infected sheep.

Hassig et al. (2003) were the first to report abortion in sheep by neosporosis. Howe et al. (2008) isolated N. caninum from aborted ewes, suggesting an association of this agent with the reproductive failure. Although not a zoonoses, infection with $N$. caninum is associated with reproductive failure, causing economic losses in affected herds (DUBEY et al., 2007).

The objective of this study was to assess the prevalence of $N$. caninum antibodies in sheep flocks raised in Uberlândia county, Minas Gerais, Brazil and associate it with the following risk factors: gender, age, race, abortion, and contact with cattle and canids.

\section{Material and Methods}

We used 334 blood samples from sheep derived from 12 farms located in the outskirts of Uberlândia, Minas Gerais. To determine the prevalence of $N$ caninum antibodies the simple random selection method and calculations were performed as described by Thrusfield (2004). We considered an expected prevalence of $29 \%$, which was the prevalence of $N$. caninum antibodies found by Aguiar et al. (2004) in sheep flocks from Monte Negro, Rondonia, Brazil. We used $95 \%$ confidence interval and estimation error of 0.05 , resulting in a sample of 317 sheep.

The number of blood samples per farm was determined using proportional stratified sampling, according to Ayres et al. (2007). Blood samples were collected randomly from apparently healthy sheep of both genders and of different ages and breeds, by puncturing the jugular vein, using disposable needles and vacuum tubes.

After blood collection, a questionnaire was applied to obtain data regarding gender, age, race, herds with abortion problems, contact between cattle and sheep, contact between dogs and sheep and presence of wild canids, according to Thrusfield (2004). We followed the rules regarding the use of animals in research and obtained permission (054/09) to perform this work from the Ethics Committee of the Federal University of Uberlândia.

Following blood collection, samples were packed in Styrofoam boxes with ice, and sent to the Laboratory of Infectious-Contagious Disease of the Faculty of Veterinary Medicine of the Federal University of Uberlândia where clot retraction to obtain serum was performed. The resulting serum was stored at $-22^{\circ} \mathrm{C}$ until serological tests were done.

Detection of $N$. caninum antibodies was performed at the Laboratory of Viral Diseases of Bovine Animal Center of the Biological Institute (São Paulo) by Indirect Immunofluorescence Assay (IFA), using a cut-off at a dilution of $1 / 50$, according to Lima et al. (2008). In each slide we used previously established positive and negative control sera and sheep-specific anti-human IgG labeled with fluorescein isothiocyanate at a dilution of $1 / 10$
(KPL, Gaithersburg, USA). Tachyzoites of $N$. caninum (strain NC-1) that were maintained by continuous passages in cultures of VERO cells CCL81 were used as antigens. Reactions were considered positive when tachyzoites showed total peripheral fluorescence, and serum samples were titrated to obtain the highest positive dilution by IFA.

Statistical analysis was performed using the program Bioestat 5.0 (AYRES et al., 2007), using a nonparametric test Odds Ratio for two independent samples to pool the results obtained, and risk factors at a significance level of 5\%.

\section{Results and Discussion}

Among all blood samples collected, 8.1\% (27/334) had antibodies to Neospora caninum, with titers ranging from 50 to 3200 (Table 1). Similar results were found in other states of Brazil, showing prevalence of $9.2 \%$ of anti- $N$. caninum in São Paulo, 9.5\% in Guarapuava (Paraná), and $8.81 \%$ in Brasília (FIGLIUOLO et al., 2004; ROMANELLI et al., 2007; UENO et al., 2009). By contrast, in Mossoró (Rio Grande do Norte), Soares et al. (2009) found a prevalence of $1.81 \%$ while in the state of Rondonia (AGUIAR et al. 2004) detected $29 \%$ positive, demonstrating the variability of results according to the region studied.

Studies performed in other countries showed similar results to those found in Brazil. In the Czech Republic and in Slovakia, studies reported a prevalence of 12 and $3.8 \%$ of anti- $N$. caninum, respectively (BÁRTOVÁ et al., 2009; SPILOVSKÁ et al., 2009).

Of all the studied farms, $83.3 \%(10 / 12)$ had at least one sheep that was seropositive for $N$. caninum, and the prevalence of this infection varied from 2.9 to $16.3 \%$ per farm. These results suggest that infection with $N$. caninum may be disseminated among the sheep flocks in Uberlândia county, Brazil. Similar results were observed in other studies: in the State of São Paulo prevalence was found to range from zero to $86.7 \%$ of herds; and in Guarapuava (Paraná) seroprevalence ranged from 4.7 to $17 \%$ (FIGLIUOLO et al., 2004; ROMANELLI et al., 2007). Aguiar et al. (2004) reported the highest occurrence of anti- $N$. caninum compared with other regions of Brazil, detecting $66.6 \%$ of the farms as containing animals seropositive for the infection.

There was no significant association ( $p>0.05)$ between sheep seropositive for $N$. caninum and gender, age, or race (Table 2), a result already shown by Romanelli et al. (2007) in Paraná. In a study conducted in Brasilia, there was no significant difference in gender (UENO et al., 2009), both sexes being susceptible to infection.

Sheep were grouped according to age, distributed in intervals of 6 to 12 months, one to four years, and over four years. Among the pure breeds commonly found in the region, we highlight the Santa Ines and Dorper. Among crossbreds, the crosses between these two races are predominant. Thus, although blood samples were obtained from sheep of different breeds, this study found no statistically significant difference between gender, age, and race.

In this study, sheep flocks with abortions had a higher frequency ( $\mathrm{p}<0.05)$ of anti- $N$. caninum, suggesting that infection with $N$. caninum may be one of the possible causes underlying reproductive problems found in sheep herds in the region. By 
contrast Helmick et al. (2002), evaluating sheep with a history of miscarriages in England and Wales, detected a low frequency of $N$. caninum antibodies $(0.45 \%)$. The study demonstrated that the reproductive failure associated with infection by $N$. caninum in these countries is low and that serological tests to study this infection in outbreaks of abortion in sheep are not justified.

Among the infectious agents that can cause abortion in sheep, Brucella ovis, Campylobacter spp., Chlamydophila abortus, Toxoplasma gondii, Listeria monocytogenes, and Leptospira interrogans stand out. There are few published data on the occurrence of natural $N$. caninum infection in sheep (MENZIES, 2007), demonstrating the need for further studies on abortion in sheep caused by this parasite (MOORE, 2005).

There was no statistical difference $(\mathrm{p}>0.05)$ when contact with cattle and dogs was analyzed (Table 2). Vogel et al. (2006) reported that sheep can participate in the epidemiology of the infection when they are raised together with bovines because cattle are considered the main intermediate host in the infection

Table 1. Prevalence of antibodies to Neospora caninum in sheep according to ownership and serological titles in Uberlândia county, Minas Gerais, Brazil, 2009.

\begin{tabular}{|c|c|c|c|c|c|c|c|c|c|c|}
\hline \multirow[t]{2}{*}{ Farms } & \multirow[t]{2}{*}{$\mathbf{N}$} & \multirow[t]{2}{*}{$\mathbf{n}$} & \multicolumn{6}{|c|}{ Titer $(\%)$} & \multirow{2}{*}{$\begin{array}{c}\text { Total of reagents } \\
\text { (\%) }\end{array}$} & \multirow[t]{2}{*}{ Prevalence \% } \\
\hline & & & 50 & 100 & 200 & 400 & 1600 & 3200 & & \\
\hline A & 345 & 24 & 1 & 2 & - & - & - & - & 3 & 12.5 \\
\hline B & 591 & 43 & 3 & 2 & - & - & 1 & 1 & 7 & 16.3 \\
\hline $\mathrm{C}$ & 153 & 14 & - & - & - & 1 & - & - & 1 & 7.1 \\
\hline $\mathrm{D}$ & 382 & 30 & 1 & - & 1 & - & - & - & 2 & 6.7 \\
\hline $\mathrm{E}$ & 580 & 41 & 3 & - & - & - & - & - & 3 & 7.3 \\
\hline $\mathrm{F}$ & 165 & 12 & 1 & - & - & - & - & - & 1 & 8.3 \\
\hline G & 500 & 35 & 4 & 1 & - & - & - & - & 5 & 14.3 \\
\hline $\mathrm{H}$ & 1000 & 70 & 1 & - & 1 & - & - & - & 2 & 2.9 \\
\hline I & 512 & 38 & 1 & 1 & - & - & - & - & 2 & 5.3 \\
\hline $\mathrm{J}$ & 200 & 15 & - & - & 1 & - & - & - & 1 & 6.7 \\
\hline $\mathrm{L}$ & 35 & 3 & - & - & - & - & - & - & - & - \\
\hline M & 90 & 9 & - & - & - & - & - & - & - & - \\
\hline
\end{tabular}

${ }^{\mathrm{N}}$ Total number of sheep in each farm; ${ }^{\mathrm{n}}$ Total number of sheep used in the experiment.

Table 2. Distribution of sheep seropositive for Neospora caninum according to gender, age, race, and risk factors in Uberlândia county, Minas Gerais, Brazil, 2009.

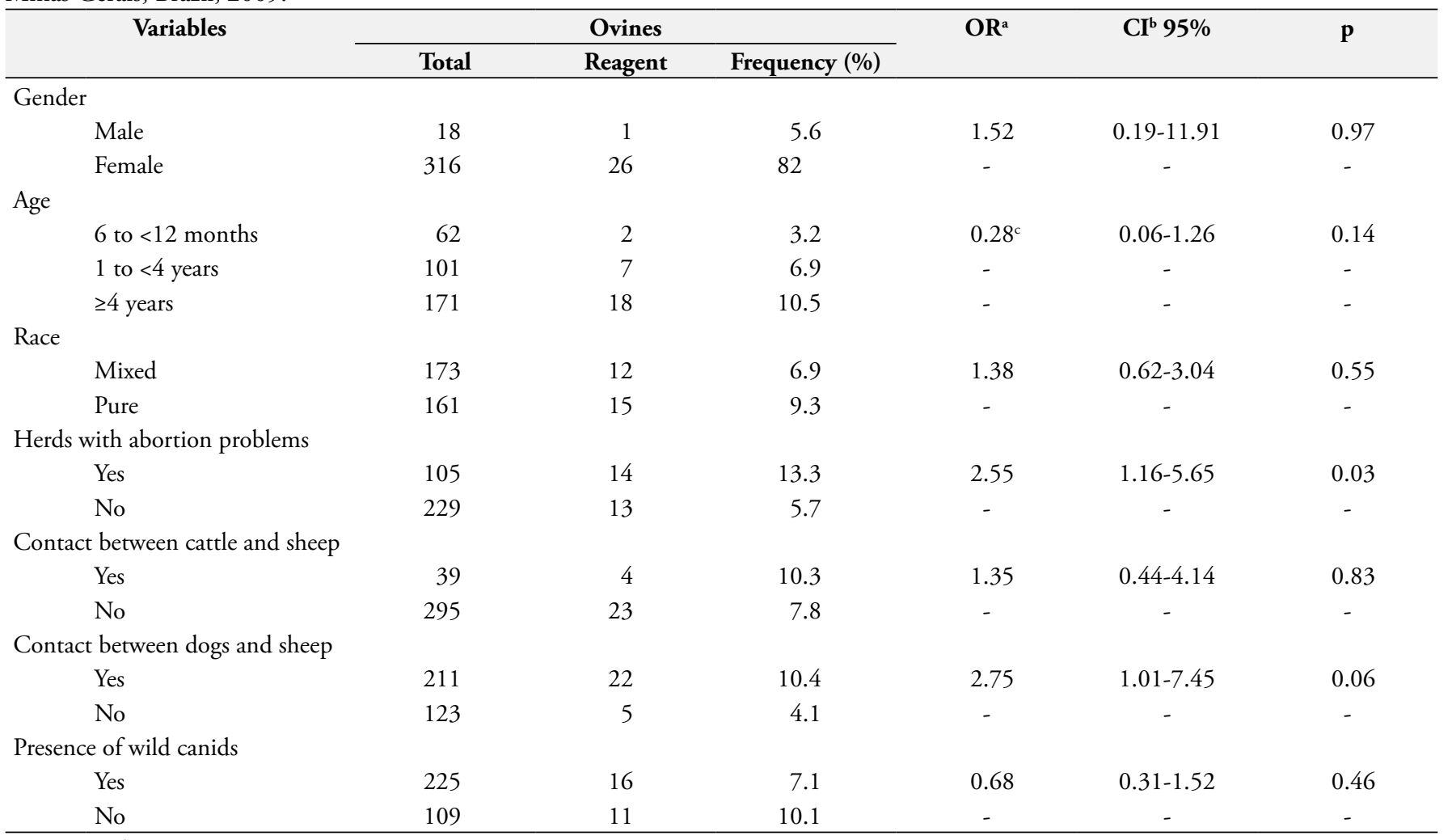

${ }^{\mathrm{a}}$ Odds Ratio; ${ }^{\mathrm{b} C o n f i d e n c e ~ I n t e r v a l ; ~}{ }^{\mathrm{O}} \mathrm{OR}$ carried out for the biggest difference between proportions; $\mathrm{p}<0.05$ shows significant difference. 
of $N$. caninum. According to the epidemiological survey, only $16.7 \%(2 / 12)$ of the farms kept cattle and sheep in close contact, although all farms owned herds of cattle.

The lack of association with the presence of canids is consistent with Romanelli et al. (2007), who also found no significant differences in the occurrence of seropositive sheep. However all farms studied owned dogs and $66.7 \%(8 / 12)$ had dogs in direct contact with sheep. Figliuolo et al. (2004) found no statistically significant difference between the presence of seropositive sheep and wild canids, a result that was also confirmed in this study.

This study demonstrated the presence of antibodies to Neospora caninum in sheep flocks in Uberlândia county, Brazil and the importance of this infection as a diagnostic aspect possibly underlying the causes of abortion occurring in sheep flocks in the region. Dubey et al. (2007) stressed the importance of implementing control measures for this infection, such as limiting the access of dogs to places where sheep herds are kept and the proper disposal of placental membranes and aborted fetuses.

\section{References}

AGUIAR, D. M. et al. Prevalência de anticorpos anti-Neospora caninum em ovinos do Município de Monte Negro, RO, Amazônia Ocidental Brasileira. Arquivos do Instituto Biológico, v. 71, p. 616-618, 2004.

AYRES, M. et al. Bioestat 5.0. Aplicaçóes estatísticas nas áreas das ciências biomédicas. Belém: Sociedade Mamiaurá, Imprensa Oficial do Estado do Pará, 2007.

BÁRTOVÁ, E.; SEDLÁK, K.; LITERÁK, I. Toxoplasma gondii and Neospora caninum antibodies in sheep in the Czech Republic. Veterinary Parasitology, v. 161, n. 1, p. 131-132, 2009.

DUBEY, J. P. Review of Neospora caninum and neosporosis in animals. The Korean Journal of Parasitology, v. 41, n. 1, p. 1-16, 2003.

DUBEY, J. P.; SCHARES, G.; ORTEGA-MORA, L. M. Epidemiology and control of neosporosis and Neospora caninum. Clinical Microbiology Reviews, v. 20, n. 2, p. 323-367, 2007.

FIGLIUOLO, L. P. C. et al. Prevalence of anti-Toxoplasma gondii and anti-Neospora caninum antibodies in ovine from Sáo Paulo State, Brazil. Veterinary Parasitology, v. 123, n. 3-4, p. 161-166, 2004.

GONDIM, L. F. P. et al. Coyotes (Canis latrans) are definitive hosts of Neospora caninum. International Journal for Parasitology, v. 34, n. 2, p. 159-161, 2004.
HÄSSIG, M. et al. Neospora caninum in sheep: a herd case report. Veterinary Parasitology, v. 117, n. 3, p. 213-220, 2003.

HELMICK, B. et al. Serological investigation of aborted sheep and pigs for infection by Neospora caninum. Research in Veterinary Science, v. 73, n. 2, p. 187-189, 2002.

HOWE, L. et al. The role of Neospora caninum in three cases of unexplained ewe abortions in the southern North Island of New Zealand. Small Ruminant Research, v. 75, n. 2-3, p. 115-122, 2008.

LIMA, J. T. R. et al. Prevalência de anticorpos anti-Toxoplasma gondii e anti-Neospora caninum em rebanhos caprinos do município de Mossoró, Rio Grande do Norte. Brazilian Journal of Veterinary Research Animal Science, v. 45, n. 2, p. 81-86, 2008.

MENZIES, P. I. Abortion in sheep: diagnosis and control. In: YOUNGQUIST, R. S.; THRELFALL, W. R. Current Therapy in Large Animal Theriogenology. 2. ed. Philadelphia: Saunders, 2007. p. 667-680.

MOORE, D. P. Neosporosis in South America. Veterinary Parasitology, v. 127 , n. 1 , p. $87-97,2005$.

PENA, H. F. J. et al. Isolation and molecular detection of Neospora caninum from naturally infected sheep from Brazil. Veterinary Parasitology, v. 147, n. 1-2, p. 61-66, 2007.

ROMANELLI, P. R. et al. Prevalence of Neospora caninum and Toxoplasma gondii in sheep and dogs from Guarapuava farms, Paraná State, Brazil. Research in Veterinary Science, v. 82, n. 2, p. 202-207, 2007.

SOARES, H. S. et al. Prevalence of anti-Toxoplasma gondii and antiNeospora caninum antibodies in sheep from Mossoró, Rio Grande do Norte, Brazil. Veterinary Parasitology, v. 160, n. 3-4, p. 211-214, 2009.

SPILOVSKÁ, S. et al. The first finding of Neospora caninum and the occurrence of other abortifacient agents in sheep in Slovakia. Veterinary Parasitology, v. 164, n. 2-4, p. 320-323, 2009.

THRUSFIELD, M. Epidemiologia Veterinária. 2. ed. São Paulo: Roca, 2004. 556 p.

UENO, T. E. H. et al. Prevalence of Toxoplasma gondii and Neospora caninum infections in sheep from Federal District, central region of Brazil. Tropical Animal Health and Production, v. 41, n. 4, p. 547-552, 2009.

VOGEL, F. S. F.; ARENHART, S.; BAUERMANN, F. V. Anticorpos anti-Neospora caninum em bovinos, ovinos e bubalinos no estado do Rio Grande do Sul. Ciência Rural, v. 36, n. 6, p. 1948-1951, 2006. 